\title{
AN ANALYSIS OF ISLAMIC JURISPRUDENCE (FIQH) AS APPLIED ISLAMIC ETHICS
}

\author{
Ahmad Badri Abdullah*
}

\begin{abstract}
As the dynamic cognitive part of the Shari'ah, figh is inclined to adapt to new challenges by adopting new methodologies and approaches. One such approach that has emerged recently is 'applied Islamic ethics'. This new ethical approach is essentially based on the principles of the higher objectives of Shari'ah (maqasid al-shari'ah) and attempts to anchor Islamic jurisprudence in its ethical dimension, which has been significantly neglected for some time. This article attempts to analyse the new approach by surveying its historical developments, its possible methodologies, the benefits emanating from its application and the possible challenges it needs to face.
\end{abstract}

Keywords: Applied Islamic ethics, ethics, figh, shari'ah, maqasid al-shari'ah, jurisprudence

\section{Introduction}

The discourse of ethics has become a major concern in various disciplines among contemporary scholars when searching for methods by which ethics could be applied as much as offering solutions to our daily practical problems. This has thus led to the emergence of the applied dimension of ethics in recent Western discourse - or 'applied ethics' - which deals with practical issues including the treatment of minorities, gender equality, animal rights, preservation of the environment, abortion, and euthanasia. In contemporary Islamic discourse a parallel concern is evident which seeks to elaborate on the practical dimensions of ethics from within the Islamic worldview. This Islamic concern may well be due to an awareness of the existing discrepancy between ethical and legal discourses in the classical Islamic legal tradition.

Classical Islamic ethical discourse basically comprised an intensive discussion of the akhlāq (virtuous character traits) along with related moral theories concerned with pragmatic ethical praxis and its theological or philosophical elaboration. On the other hand, the legal tradition of Islam may be suffering from an obsessive focus upon legalistic aspects of rulings and to some extent from the absence of ethical concerns which fall outside of its traditional purview. This issue previously triggered the utmost concern of classical scholars such as al- Ghazzālī in his Ihya' ' 'Ulum al-Din as well as certain contemporary scholars including Mohammad Hashim Kamali in his Freedom of Expression in Islam and Tariq Ramadan in his Radical Reform. The renewed emergence of applied ethics in Islamic tradition is also attributable to the recent awareness of the importance 
of identifying the higher objectives of Sharī'ah (maqasid al-sharī'ah) to govern the process of promulgating laws, since these objectives pertain to specific ethical principles such as justice, equality, and human dignity.

\section{Identifying the Realm of Applied Ethics in the System of Islamic Jurisprudence}

As explained by Ebrahim Moosa, 'applied Islamic ethics' juxtaposes two different discourses in Islam, namely the juridical-moral discourse ('ilm al-fiqh) and the ethico-moral discourse ('ilm al-akhlaq, also adab). ${ }^{1}$ Given that applied ethics is closely related to the topic of maqāsid al-sharì $a h$, it may contribute to enriching and complementing such discourse by integrating essential elements of Islam encompassing its legal, moral, and spiritual dimensions. To identify the sphere of applied ethics in the system of Islamic jurisprudence, it is imperative to delineate the most important concepts embodied in the system: sharī 'ah, fiqh, qanun, and 'urf.

The word fiqh is used in the two main sources of Islam - the Qur'an and Sunnah - in a variety of meanings, but generally conveys the core meaning of 'understanding' (synonym of 'aql or fahm). However, after the establishment of the classical Islamic schools of law, figh generally came to indicate "a body of knowledge of practical revealed rulings extracted from detailed evidences". ${ }^{2}$ Shari 'ah on the other hand implies another significant meaning. It is employed in the Qur'an to denote the 'revealed way of life'. ${ }^{3}$ Putting it differently, fiqh represents the cognitive aspect of Islamic law, while Shari ah represents the revealed aspect of the law. ${ }^{4}$ The distinction between figh and Shari ${ }^{-} a h$ is not a matter of concern for classical discourses of Islamic legislation, since the classical jurists viewed fiqh as 'sacred law'. Similarly certain schools of figh have been adopted into the laws of modern states, being perceived as the very Divine law which needs to be followed in a strict sense. ${ }^{5}$

The word qānūn was originally Greek (c.f. English canon - 'ordinances, established rulings') which was taken up into Arabic and then Persian and Turkish. Since the nineteenth century this term was extended in Arabic to connote a body of written laws, whereby in countries which endorse Islamic law some written laws represent the adoption of certain rulings or legal opinions (fatāwa $)$ drawn from one or more classical schools of figh. ${ }^{6}$ Moreover, a number of written laws in Islamic countries are purely based on local practice or customary tradition termed 'urf. 'Urf denotes customary practices approved by a community, and constitutes an important topic within the sphere of figh as a source of legislation. However, a number of scholars regard 'urf to be merely an effective factor in applying certain rulings, rather than being a credible basis in its own right for ascertaining those rulings. ${ }^{7}$ 
It is also important to note the intersections between such key concepts when locating the ethical element embedded in those theoretical concepts as well as in their application. To explain these relations it may be useful to refer to a diagram offered by Jasser Auda which illustrates the intersections between all the abovementioned concepts. In this diagram the Sharī ah is shown to consist of the Qur'an and the prophetic traditions as its main reference. Rulings of fiqh are thus deduced from those two referents of Shari' 'ah, while on the other hand the qānün are written laws which might be the adoption of rulings in figh or 'urf practices, or even from other sources. ${ }^{8}$

Diagram 1 The (traditional) relations between the concepts of Sharī'ah, fiqh, and $q \bar{a} n \bar{u} n^{9}$

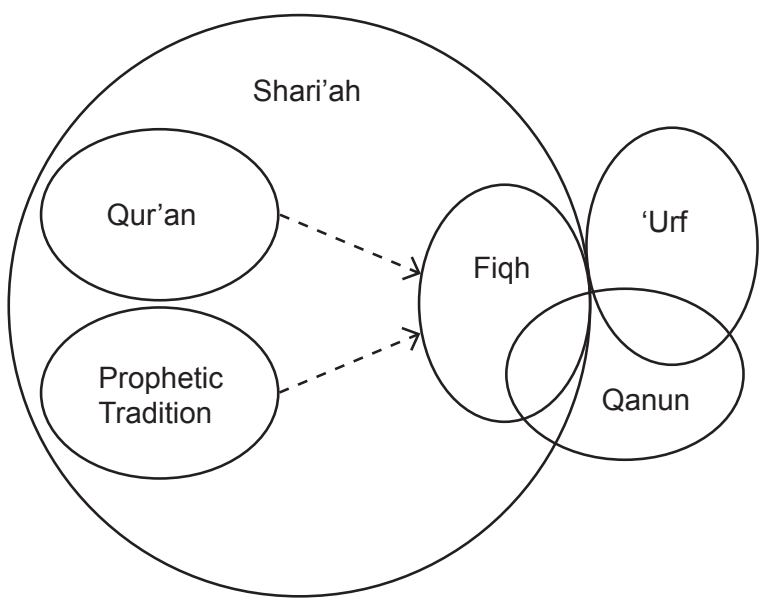

In essence, ethics covers all the elements in this diagram ranging from Sharì' ah, fiqh, qūnūn, and 'urf, since ethics is clearly a major concern of Islamic teachings especially those embedded in the Qur'an. As the Qur'an and the prophetic traditions of Sunnah attach great importance to ethics regarded as an important objective of Islamic teachings, it may be stated that the Shari' ah is the main ethical source for Islamic ethics. In this sense, Kamali has contended that the concepts of Islamic law and ethics originated from the fundamental notion of tawhìd ('Oneness') - for the Lawgiver is the sole source of norms and values. ${ }^{10}$ Moreover, our research argues that fiqh - as being suggested as well by Kamali as a mean in realising ethics ${ }^{11}$ - and specific parts of $q \bar{a} n \bar{u} n$ are the central points in order for applied Islamic ethics to be identified and realised since both deal with the practical conduct of Islamic legislation. However, there are some 
discussions pertaining to this assumption just as there are complexities in the relation between the three concepts of fiqh, qānün and ethics. To illustrate this, we propose a new diagram which explains the relationship of ethics with all those legal concepts, including the realm of reason, given that the full range of Islamic ethical discourse incorporated both philosophical and theological components. ${ }^{12}$

Diagram 2 The place of Islamic ethics and of applied Islamic ethics in their relation with other Islamic legal concepts

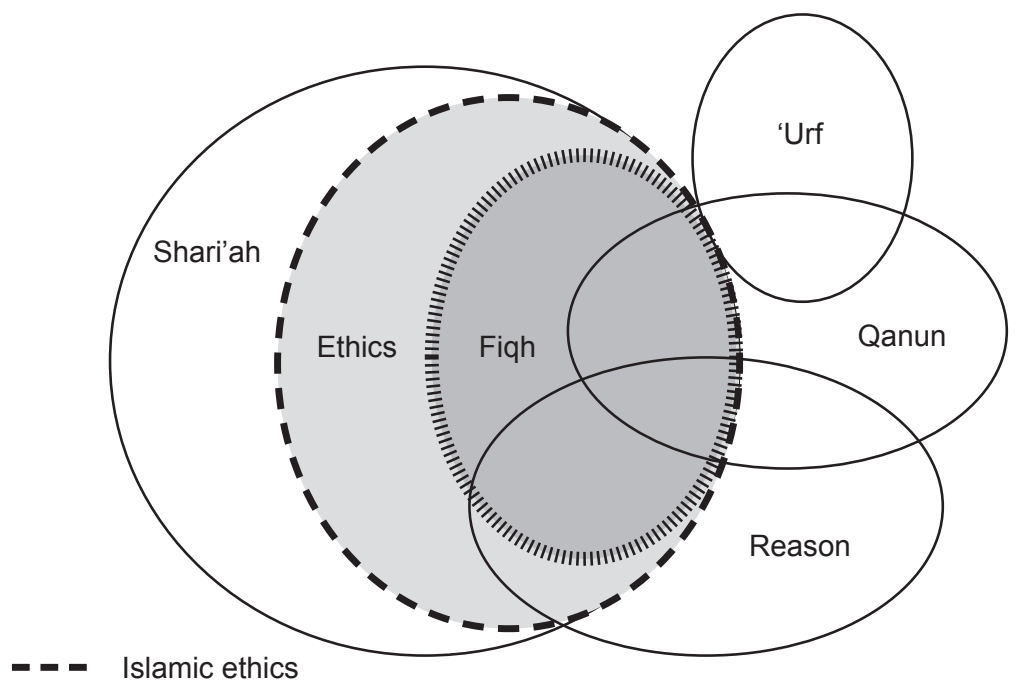

IIIIIIIIII Applied Islamic ethics

Majid Fakhry, who authored a good historical overview of Islamic ethical theories, provided a useful classification of Islamic ethics ${ }^{13}$ - scriptural ethics, philosophic ethics, theological ethics, and normative religious ethics - yet he appears to neglect the ethical dimension offered by Islamic jurisprudence or fiqh, which 'A. H. Zaroug has asserted to be the most fertile area in Islamic ethics. Zaroug also maintains that among Muslim scholars, the jurists have made essential contributions to the field of practical ethics in Islam. They have promulgated the benchmark in evaluating the ethical values of actions that is in conformity with the Shari' ah sources of the Qur'an, the Sunnah, consensus (ijma $\bar{a}^{\prime}$ ), customs ('urf), the principle of utility (mașlahah), appropriate referential rules like analogy (qiyass), and certain legal maxims. To state this in another way, the principles and inferential rules found in the roots of Islamic jurisprudence (ușül al-fiqh) are indeed the very methodological framework for evaluation of ethical conduct within the Islamic world-view. ${ }^{14}$ 
Similarly to Zaroug, K. Reinhart argues that Islamic ethics could be referring only to Islamic law and legal theories due to the ethical traits which form a practical discipline. Thus for Reinhart the philosophic, theological, and cultural praxis are excluded from the radius of Islamic ethics. Properly understood, Islamic "law" which Reinhart refers to as figh - is not merely law, but indeed is an ethical and epistemological system of great subtlety and sophistication. Moreover, Reinhart argues that the five categories of acts enunciated by fiqh - obligatory (wäjib), prohibited (harām /maḩzūr), recommended (mandūb), discouraged (makrūh), and permitted (mubāh $)$ - is not merely the Islamic understanding of the abiding moral form of life, rather it is at the same time a repudiation of the accuracy of the simple bi-polarity moral categorisation of good and bad. Moreover, this five-fold moral categorisation rather than the simple bi-polar system, represents an inclusive moral system, since it recognises the two-tier membership in Muslim societies: those who live between the boundaries of obligations and prohibitions, and those who strive to adhere to the recommended and to avoid discouraged acts. ${ }^{15}$

\section{The Scope of Ethics and General Characteristics of Islamic Ethics}

Ethical discourse may be divided into four main topics of discussion: descriptive, normative, meta-ethics, and applied ethics. ${ }^{16}$ Descriptive ethics provides reports on the actual moral conduct governing the behaviour and practice in a particular society without judging those local moral principles. Normative ethics performs the descriptive and justificatory part of ethical discussion, for it includes justification of suggested ethical conduct in specific conditions. There are a number of justifications of ethical conduct, which are contingent upon the school of ethics which is involved in such discussion, including consequences (promoted by consequentialists), universality (like Kant, i.e., deontology), or as a result of contract (with J. Rawls) ${ }^{17}$, Divine commands (i.e. religious ethics), and natural laws (naturalists).

Applied ethics is concerned with applying general ethical theories (i.e., deontology or consequential theories) to specific issues in the pursuit of identification of moral values, without regard to the justification of those ethical codes or the means to resolve the issues of ethical divergence. ${ }^{18}$ Finally, metaethics tries to provide answers to essential questions pertaining to ethics such as: 'What is the meaning of the word Good?', 'What is the nature of moral statement', 'How to distinguish between moral and immoral?', etc. Historically speaking, the Western discourse on ethics has moved from a concern with meta-ethics, then to a concern with normative ethics, and more recently to applied ethics. ${ }^{19}$

Zaroug also attempted to provide some scope in defining the features of ethics in a general sense, and has summed up the features of an Islamic ethical system. He suggested that Islamic ethical systems theoretically comprise a number of 
essential elements: in the form of prescriptive ethical statements as universally valid features which apply to all parties in any circumstances - except that in Islam there are certain legal prescriptions which only apply to the Prophet $(S)_{-}$ actions which are made voluntarily with underlying intention, and are associated with certain feelings and emotions, and that finally they must be practical. ${ }^{20}$

\section{Ethical Elements of Islamic Theological Discourse and its Influence on Jurisprudence (Fiqh)}

Classical Islamic scholars often discussed the 'virtuous character traits' or ethics at an abstract level, thereby neglecting their pragmatic relation to the realm of Islamic jurisprudence. The divide between virtue ethics and applied ethics is deep for it pertains to the creedal basis relating to the discourse of kalam. This divide also reflects the question whether all of the actions of Allah All-Mighty are purposeful - including the purpose of His revealing His guidance and divine Law to humankind. ${ }^{21}$ The answer to this foundational question gave rise to a divergence of opinion among the various Islamic theological schools (madāris ilm alKalām). However, before discussing this issue at length, it is noteworthy that these theological speculations even though left significant impacts on the Islamic legal theories, had shunned positive laws of the respective schools, as the influences of those legal theories were so limited on the laws applied in actual context. ${ }^{22}$

For example, the typical Asha arite answer to this critical question is that Allah does not require any purpose when revealing His commands and prohibitions, or at least that His ultimate purpose may not necessarily be comprehended by humans and He is not obliged to command what is good for His subject, rather His commands are the sole benchmark of the notion of good and bad for them. ${ }^{23}$ Therefore, Islamic jurisprudence need not be based on explicit ethical intentions manifested by the Lawgiver. The Law only refers to the understanding derived from the textual sources (nașs) through its linguistic implications. According to the Ash 'arite perspective, the first step in understanding God's Law is to analyse the words and derive the linguistic implications (dalālat al-alfāz) from the text in order to extract rulings from it. The second step is to extract the ethical dimensions from these rulings. In short, for theologians ethics are derived from the Law and the Law is derived from the linguistic implication of the divine text. Therefore, this kind of perspective does not accept any underlying virtues and purposes as the basis of the text. Purposes or virtues are not seen as the preexisting basis because they follow after the process of extracting the Law. As a result, all commands from Allah in the texts must be obeyed irrespective of their apparent rationality; and through such obedience in applying the rulings, humankind will certainly gain benefits whether at the individual or the communal level. ${ }^{24}$ This voluntarism approach on the nature of good and bad and the Divine 
commands replicated itself in the Shafi'i school of jurisprudence as it emphasised on rulings from explicit texts and rejected the other pragmatic legal sources such as istihān, sadd al-zarā' $i$, and masālih al-mursalah. ${ }^{25}$

On the contrary, the Mu tazilah theology took an opposing point of view, for they asserted that all actions performed by Allah are rational with definite purposes and virtues. Nevertheless in the realm of jurisprudence, they did not allow virtues to serve as the basis of practical rulings $(a h k a \bar{a}) .{ }^{26}$ Indeed the jurisprudence adhered to by most Mu tazilah theologians was often Hanafi $f i q h^{27}$ along with Shāfi 'i ușül al-fiqh which shared the common yearning to extract the Law linguistically directly from the texts. Some of the $\mathrm{Mu}$ tazilah adhered to the Mālikī or the Zaydī schools of fiqh, while among the Imāmī Shī'ah there developed a Mu'tazilah-inspired kalām combined with Ja farī jurisprudence. Although the $\mathrm{Mu}$ 'tazilite upheld that mind and rationality took precedence over revealed texts, yet eventually they only applied laws which were directly derived from the linguistic implications of the texts. Despite espousing their methodology of tahsin and taqbīh in doctrinal matters, which asserts that the human mind has the innate ability to ascertain goodness and badness, the Mu tazilah refrained from applying this distinction in the realm of jurisprudence.

The Māturīdī theologians occupied a middle ground between Asha' arites and Mu'tazilah. They taught that Allah observes His own purpose when revealing the Shari ' $a h$ but this purpose arises out of His own generosity and bounty. Allah is not obligated by His purpose - as the Mu tazilah asserted - but He maintains the rules out of His mercy and compassion. ${ }^{28}$ When they handled Islamic jurisprudence the Māturīdī thinkers certainly adopted Ḥanafì fiqh, being however different from Shafi ${ }^{\prime} \overline{1}$ fiqh in certain points - e.g., when describing the categories of linguistic implications between 'āmm (general) and khāsș (specific), muțlaq (absolute) and muqayyad (confined) ${ }^{29}$ — but the dissonance between their methodology of Law derivation and the virtuous or ethical essence of the Shari ${ }^{-} a h$ remained. The methodology and ethics remained disconnected and played their own separate roles according to the Māturīdī school's perspective. ${ }^{30}$

There was another school of thought which adopted a different viewpoint on this same topic of discussion, namely the 'theoretical objectives' school. The forerunners of this school who included Ibrāhīm Ibn Mūsā Ibn Isḥāq al-Shātibī (d. $790 \mathrm{AH}$ ) and Ibn Qayyim al-Jawziyyah (d. $751 \mathrm{AH}$ ) put their utmost concern on the 'purposes' and 'interests' as the basis of Islamic jurisprudence. This is evident in the famous quotation from Ibn Qayyim that: ${ }^{31}$

Sharīah is all about justice, all about wisdom, and all about public goods. So any ruling that takes Sharī ah from justice to injustice, from wisdom to stupidity, and from public good to mischief is not Sharīah even if it is claimed to be according to some kind of interpretation. 
Further al-Shātibī in his al-Muwāfaqāt describes the objectives and higher purposes of Law (maquassid al-Sharī'ah) as the "Universal of evidences and the universal of faith". ${ }^{32}$ For him, the preservation of faith, life, intellect, progeny, and wealth is not just the basis of law but more importantly they serve as the basis for faith as well. His consideration that this purposes is the underlying basis of law is clear in his conclusion that "the particulars are not supposed to contradicts the universals. ${ }^{33}$ It is clear that the methodology of al-Shātibī and Ibn al-Qayyim differs from the classical theologians, in that both approach the Shari 'ah through its higher purposes and are not confined by the linguistic spectrum of texts. ${ }^{34}$ This approach implicitly claimed that the purposes, objectives, and virtues are the basis of Shari 'ah law. However, in this school of thought, the divide remained between philosophical ethics and applied ethics as Ibn Qayyim himself in his legal opinions did not apply this ethical approach consistently especially in his work titled I' 'àm al-Muwaqi 'in 'an Rabb al- 'Álamīn. ${ }^{35}$ Similar to Ibn Qayyim, alShātibī himself also failed to maintain the consistency of these higher principles in his Fatāwā Imām al-Shātibī which displays a typical Mālikī stance in fiqh ${ }^{36}$ Nonetheless, to some extent he did give weight to public interest and common good in his legal opinions except to the realm of worship ( $i b \bar{a} d a h) .{ }^{37}$

In short, in this brief account of the historical unfolding of Islamic jurisprudence, it exhibited a clear divide between ethics and law which remains intact until today. One reason behind this divide is the existence of the notion of the 'act of worship' (ta 'abbudiyyah) that has to be taken directly and literally as it is in the texts. ${ }^{38}$ This is in contrast to the 'transaction' (mu 'amalah) that must be taken based on wisdom and interest. According to al-Shātibī for example: "the act of worship must be taken literally but the transactions must be taken based on wisdom, purposes, and virtues. ${ }^{39}$ However, as Auda argued, an issue arises here since the distinction between the former and the latter is not precisely clear. ${ }^{40}$ For instance, some Islamic legal theorists (ușülīs) discussed the 'irrationality of the wisdoms' implicit in demonstrating all acts of worship to be deeds which are impossible to be rationalised by humans. This is subject to the simplicity of the scholars who never tend to change any rule they were not able to grasp the virtues or wisdom (hikmah) behind it - despite changes of time, traditions, cultures, etc. - with the consideration that the rule may probably fall into the category of 'acts of worship'. Thus, the definition of acts of worship remains obscure. Al-Āmidī attempted to define such acts by "the rights that cannot be declined or wavered", for example the dowry in marriage even if it is manifested as a symbolic element. ${ }^{41}$ This type of definition eventually resulted in diluting the 'act of worship' from its ethical dimension. Al-Ṭüfi also tended to define the 'act of worship' in the same way when he described that all rulings defined in numbers such is in zakat , inheritance, and family law should supposedly not be touched. ${ }^{42}$ 
Eventually this unclear distinction or inconsistent definition of the acts of worship resulted in maintaining the gap between Islamic virtues and laws. Abou Fadl illustrates this situation by maintaining that this problem stems from the normative approach of jurists in dealing with specific laws ( $h u d \bar{u} d)$ which are explicitly commanded by God, as if these laws, in themselves are the sole manifestation of ethical concepts in Islam. Hence, this approach led them to focus on the external part of the law itself, for instance types of punishment in Islamic criminal procedures, rather that upon the behaviour and conduct that warranted such punishment. Abou Fadl thus argued that ethical values are not embodied in the severe punishments, but they are in fact operative in behaviour and immoral conduct which the laws seek to inhibit. For example, in consumption of alcoholic beverages, the ban of unethical conduct is the actual value of the ruling just as it forms part of the Shari ' $a h$, and is not solely the punishment enacted in the textual evidence per se. ${ }^{43}$

\section{Bridging the Divide between Islamic Ethics and Islamic Jurisprudence}

In Western tradition there is a debate among legal theorists regarding the role of morality in law, specifically the dissension between the positivist theory which maintains law to be amoral, and the interpretive theory which proclaims that ethics and morality shared in a particular society may bring about influences on its law. To the contrary, enacted laws may also contravene ethics and morality - for example laws which approve the practise of slavery or discrimination. ${ }^{44}$ Mohammad Hashim Kamali argued with regard to this issue that the distinction between Islamic law and morality lies in the five fold moral categorisation within the system of Islamic jurisprudence, whereby the obligatory and forbidden have their legal implications, while the three remaining intermediate concepts encouragement of the recommended and avoidance of the reprehensible - lie in the realm or morality or ethics which cannot be adjudicated as laws. Nonetheless, Kamali pointed to the fact that in the historical background of Islamic societies there was another institution that played a role in safeguarding morality, namely the institution of hisbah. This is an illustration of the imperative part taken by the Muslim Ummah in promoting ethical values in general..$^{45}$

However Johansen has mentioned an interesting situation where state laws relegated some provisions in fiqh identified as unethical, and afterwards replaced them with ethic-laden laws which gratify the universal principles of maqassid al-sharī $a h$ as well as mașlahah. For example, there was a judgement made by the Egyptian Supreme Constitutional Court, which rejected actions of a father who demanded the court declare Article 18 bis (2) of law no.100/1985 (which declared the father liable for the maintenance of his children from the date on which he refused to supply them with such maintenance) to be unconstitutional. 
The plaintiff claimed that this article contradicts the dominant doctrine of the Hanafi legal school that requires the father to fulfil the maintenance needs of his children, rather being only related to his personal obligation in a certain specific condition, which is in fact difficult to bring into real practice. The Court instead adhered to Article 9 of the Egyptian constitution which mentions the state's responsibility to protect the family institution and principles of Shari 'ah, and thereby refused to abide by Article 2 or that it needed to identify rulings from certain schools of figh. The Court finally ruled that the father, who failed to provide his children with sufficient maintenance, would be forced to do so. ${ }^{46}$

Nevertheless, there are still alarming issues pertaining to the gap between morality and figh that require careful judgement. Fiqh can only serve as the interpretative enterprise of Sharī 'ah in the case that the practise of ijtihäd is taking into account, along with due observance in upholding the principles of maqāsid al-shari 'ah. Unfortunately, some of the traditional rulings of figh were deprived of the true ethical spirit of the Sharì ah itself. This departure of figh from its ethical dimension is due to a number of reasons. ${ }^{47}$ The main reason is the stage of stagnation suffered by this body of knowledge with the obstruction of ijtihād and the calling for taqlid throughout the third, fourth and fifth Islamic century ${ }^{48}$ which finally lead figh to embrace the technical complexities and burdens coupled with the ignorance of its ethical elements. Moreover, through a type of instrument provided in the Islamic legal systems namely the legal stratagem (hillah alshar 'iyyah), ${ }^{49}$ ethical elements such as the observance of others' rights, charity, benevolence, and honour in the rulings of figh were managed to be completely ignored. ${ }^{50}$

To cite an example: even though debt is basically permissible in Islamic law through different financial tools such as muräbahah, bay' al-mu'ajjal, salam, istisn $\bar{a}$ ' and the like, moral issues may arise related to its size. There are in fact several anecdotes from prophetic tradition which denounced excessive indebtedness, as the Prophet himself firmly advised Muslims to avoid any engagement with debt as far as they could. ${ }^{51}$ There was even an incident where the Prophet refused to lead the funeral prayer over someone who had died indebted. ${ }^{52}$ Moreover, the adverse consequences of debt on societies are evident after major global economic crises in recent years. Therefore, if activities of Islamic banks are merely the expansion of business by promoting financial services which may increase the debt level in markets, even if they are supported by certain technical and legal procedures labelled Islamic, they may actually be contributing to unethical practices since they ignore the impact of debt on public welfare and Islamic moral teachings. ${ }^{53}$

In the view of Auda, this divide could be bridged by initially clarifying the clear distinction and classification between the variable (mutaghayyirāt) and the 
constant (thawābit) elements in Islamic jurisprudence. The immutable should be the category which embraces pure acts of worships relating to acts of prayer, pilgrimage and fasting as well as those rulings prescribed quantitatively as stressed by al-Tüfí. When this type of act is fixed, then everything else excluded from this category will be analysed and judged within the purview of ethics. This will provide the flexibility to realise the ethical dimension of Islam in different circumstances, across different traditions, cultures, and time. In this state of clear compartmentalised spheres between the two domains of 'ibädah and mu'ämalah, a new discipline of 'Islamic applied ethics' could emerge. ${ }^{54}$

Eventually, Islamic jurisprudence might become apprehended as an Islamic applied ethic, or to put it differently: applied Islamic ethics may become Islamic jurisprudence in its contemporary form whose focus is placed upon its ethical dimension rather than its legalist implications. Thus, the commands and prohibitions within the stipulations of Islamic jurisprudence need to be analysed on the basis of their ethical contents. In this approach to ethics, the divine textual evidences (naș al-wahy) are the major source of virtues, in addition to the vast heritage of legal opinions drawn from the living law schools, and classical discourse on practical and philosophical ethics. ${ }^{55}$

\section{Radical Reform in Establishing a Framework for Applied Islamic Ethics}

T. Ramadan has exhaustively discussed the approaches and methods towards establishing an applied Islamic ethics at its theoretical level as well as its pragmatic aspects. He argued that it is imperative to move the centre-of-gravity of authority in Islamic traditions from the domination of textual disciplines of the Divine script to the dynamic interactions between textual and contextual disciplines. These two spectrums of knowledge should be considered as the source of contemporary Islamic jurisprudence as well as the basis for establishing higher principles or objectives of Sharī $a h$ Law. Afterwards comes a later process which involves both the scholar of texts working together with the scholar of contexts referring to the framework of the higher objectives, working together in elaborating an applied Islamic ethics for various fields of specialisations ranging from the natural sciences, ecology, culture, economics, politics, gender studies, and education. Therefore, in order for this project to be realised, textual scholars need to be accompanied by practitioners and specialists in experimental and medical sciences, as well as economists, lawyers, or sociologists to inform them about the state of knowledge or the potential consequences of some particular techniques or scientific practices. In Ramadan's view, the presence of such specialists collaborating with textual scholars on the committee of fatwās working in the framework of higher principles and objectives reform - would constitute a radical reformation of Islamic jurisprudence at the methodological level. ${ }^{56}$ 
Moreover, Ramadan agreed - following in the footsteps of classical scholars such as Ibn Taimiyyah (died $728 \mathrm{AH}$ ) as well as contemporary scholars such as al-Qaradawi, Kamali, and al-Raysuni - that the classification of the higher objectives into three levels of darūriyyāt, hajiyya $\bar{a}$, and tahsiniyyāt encompassing basic components of human life of the preservation of faith (al-din), life, intellect, progeny, and wealth, are not really sufficient in facing the new reality of the post-modern world. He suggested a new and broader classification of the higher objectives. Before laying out his suggestion, Ramadan lamented over the classical classification of maqāṣid which included al-dīn (religion, or 'faithpractice') along with preservation of body and mind and consideration of the punitive sanctions ( $h u d \bar{u} d$ ) which implicitly suggest that all these elements need to be protected. This leads to the negative implication that reduces the concept of al-din only to the pillars of Islamic creed ('aqidah) and the ritual practices ('ibadah). Ramadan suggested a broader understanding of al-din for this new classification to embrace the recognition of Tawhìd on all levels and also include the notion of maslahah as everything created and devised for the welfare of humans. Therefore the most important purpose and objective of Shari $a h$, is the protection of both al-din in its broad conception of life and death stemming from the recognition of mașlahah. ${ }^{57}$

In Ramadan's understanding, the pillars of the two most important abovementioned objectives on the next level of classification stemming from contemporary analysis of the two books (contextual and textual inferences) are the protection of life (hayāt), nature (khalq, țabì $a h$ ), and peace (saläm). On the third level come the objectives directly related to human actions. The list of objectives ranges from the protection of dignity, welfare, knowledge, creativity, autonomy, and development, to equality, freedom, justice, fraternity, love solidarity and diversity. These three levels of objectives are general and inclusive, and need to be supported by three further levels consisting of many higher practical goals which assist in the effort of elaborating an applied ethics. Ramadan differentiated these levels into categories determined by the 'inner being', the 'individual being' and the 'being in the group'. The 'inner being' is the spiritual dimension of the human which should be encouraged and protected to ensure the balance between heart, mind and body in every aspect of their life. This consists of several objectives being the education (of heart and mind), conscience (of being and responsibility), sincerity, contemplation, balance, and humility. The 'individual being' on the other hand, is the category pertaining to individual rights and responsibility in a wider sense. It consists of nine objectives being the protection of physical integrity, health, subsistence, intelligence, progeny, work, belongings, contracts, and of the neighbourhood. The third category of objectives relates to the social dimension which is often absent from the discourse of classical scholars. It 
also encompasses nine objectives that relate to essentials in human society in consideration of post-modern globalised world realities and include promoting and protecting rule of law, independence, deliberation, pluralism, evolution, cultures, religions, and memories (heritage).

These are the new classifications of the Sharī'ah objectives (maqāșid) that have been suggested by contemporary readings of the textual and contextual inferences, which perhaps could perform an important role as the framework for a contemporary applied Islamic ethics.

\section{Classical and Contemporary Ethical Discourse as Beneficial Resources for Applied Islamic Ethics}

Classical Islamic ethical discourses are indeed a rich intellectual and practical heritage, which should not be neglected in the process of formulating contemporary applied Islamic ethics. By referring to the classification of theories of Islamic ethics made by M. Fakhry, we may benefit from useful discussions on practical ethics as well as philosophical ethics, which may assist and inspire scholars in their quest of identifying applied ethics related to current issues. ${ }^{58}$

Al-Ghazzālī (d. 505/1111) dealt with the discourse of akhlāq (morality) in some of his major works including Ihyā' 'Ulüm al-Dīn and Mìzān al- 'Amal. His structure of discussion pertaining to ethics is almost similar to those of Miskawayh in his Tahzīb al-Akhlāq, though with some additional discussions on the practical aspect of ethics. Al-Ghazzālī has provided a thorough discussion pertaining to eating and table manners, where he clarifies that food worth eating is that earned by legitimate and honest means recognised in Islamic principles. $\mathrm{He}$ also addressed important codes of conduct when someone is invited as a guest in another's house and manners to observe in organising a feast. He then touched on other aspects of ethics related to the pursuit of earning and making a living and economic activities. In al-Ghazzālī's ethical system, the governing principles pertaining to the earning of livelihood are: fair dealing, justice, and beneficence. It is interesting to notice the notion of benevolence according to alGhazzāli where he incorporates ethical prescriptions with certain fiqh rulings in dealing with the acts of earning - specifically in buying and purchasing goods, money lending, as well as in debt payment. ${ }^{59}$ There are six kind of benevolence according to al-Ghazzālì:

(a) If a person needs a thing, one should give it to him, making as little profit as possible. If the giver forgoes all the profits, it is better for him.

(b) If a man purchases anything from the poor, it is more graceful to pay him more than the original price. However this is not the case with the wealthy person. 
(c) In realising one's loans, one must act benevolently by giving the debtors more time to pay his debt, and if possible one should make reduction from the original amount of debt so as to provide relief to the debtor.

(d) People who want to return the goods they have purchased should be permitted to do so.

(e) It is preferred that a debtor pays his loan without being asked to do so, and if possible long before the due time.

(f) In selling something on credit, the seller should be generous not to press for payment for the customer who is unable to pay on the agreed terms. ${ }^{60}$

Those who are able to secure justice and maintain fair mindedness in their daily business transactions for al-Ghazzālī will be regarded as among the al-șāliḥūn (righteous ones), while the person practicing benevolence in their dealings is among the al-muqarrabün (near ones to God). Indubitably, these principles of benevolence are worthy of consideration for scholars in formulating Islamic business ethics.

It is also noteworthy that al-Ghazzālī's description of certain legal concepts is infused with values and ethical norms. He touched on the status of halāl, $m u b \bar{a} h$, and wäjib as well as issues related to all these concepts. Even though the concepts are focal points in figh discourses, al-Ghazzālī infused in interior ethical dimension within those concepts. This is visible in his discussion about the level of abstinence (wara') among the believers, which comprises four distinctive levels. Wara' al-'adūl is the lowest level of avoidance of things which are declared as prohibited; wara' al-șâlihün is abstention from things whose status is unclear; wara' al-muttaqīn is the abstinence from haläl in which indulgence may eventually lead to haram; while the final level is the wara' al-siddiqün which is abstention from the intrinsically haläl elements for the attainment of God's good pleasure. In contrast, permissible elements or practices (mubāhāt) according to al-Ghazzālī are able to eventually lead someone into unlawful actions for the human mind that is too attached to those permitted things may gradually bring someone to indulge in something which is impermissible. Thus al-Ghazzāli explains that an unmarried person who indulges in using perfumes or consuming foods would trigger his sexual appetite, and this eventually leads him to commit sins. ${ }^{61}$ However, this conclusion was refuted by al-Shātibī's description of the status of permissibility (mubāh) where he argues that the true mark of asceticism is abstention from those actions which we are required by the Lawgiver to abstain from..$^{62}$ Moreover, in describing the concepts of obligatory acts (wujūb), al-Ghazzâli related those acts to the elements of harm that may spring from their omission, which is termed by G. Hourani as 'prudentially necessary'. Expected harm in this definition may happen to be the harm in worldly life that is known by intellect as well as in the next life that is known by revelation. ${ }^{63}$ 
One important contemporary studies on ethics is by 'Abd Allah Draz entitled 'The Moral World of The Qur'an' (Dustūr al-Akhlāq fì al-Qur'ān), which is considered a milestone in modern studies of Islamic ethics. He aimed to fill the gap in Western history of moral philosophy created by its ignorance of Qur'anic ethics, and to show that the moral insights of philosophers are implicit in the Qur'an. ${ }^{64} \mathrm{He}$ identified key moral concepts including obligation, responsibility, moral sanction, intention, motivation, and effort. For him the concept of obligation is the most compelling moral elements in the Qur'an in which a reconciliation between three elements take place: innate ideas (fitrah), freedom, and revelation. He also attempted to apply moral law to practical situations, with a note that there are types of indeterminacies in applying the laws to real situations without having to violate those laws. ${ }^{65}$ Ramadan observed the contribution of Draz in highlighting essential values in the Qur'an through reading the Qur'an in its entirety as well as certain passages which are not related to legal issues.

Another dimension that certainly would be useful for scholars in the quest of developing an applied Islamic ethics is the philosophic discussion of ethics, for in any ethical system there should be incorporated a clear concept of the human being and motivation for deeds. Classical Islamic discourse pertaining to ethics embraces a profound discussion on the nature of human soul and its perfection. Miskawayh dealt with this psychological subject in his works where he delineated his concern on the nature of the human soul and its innate ability to discern true and false. With the help of this rational faculty the soul is inclined to goodness and this eventually will lead the soul towards its perfection. ${ }^{66}$ Ramadan also postulated three main themes in the Islamic ethical system which delineate the concept of human being in relation to scriptural sources from the Lawgiver: the intellect, freedom, and innate moral sense. Intellect signifies the ability of humans to utilise their rational faculty so as to explicitly or implicitly extract meanings from the divine texts. Freedom signifies the relation between obligations and responsibilities whereby human beings are free to either fulfil or neglect those obligations and responsibilities subjected to them. With regard to the innate moral sense, it conveys the reality that humans are equipped with an innate or natural sense of morality so as to analyse and evaluate their conduct. These concepts may provide the maquassid al-sharī' $a h$ with a philosophic dimension taken into account for the purpose of legislation. ${ }^{67}$

\section{Promoting the Ethical Dimension of Islamic Jurisprudence}

In the Islamic perspective an action is regarded as ethical whenever the elements of its higher objectives (maqasid) are being satisfied. This involves among other things: honesty, trust, transparency; while in transactions it requires linking 
returns to risk, and bearing the risk of ownership. Furthermore the elements of intention (niyyah) and consequence ( $m a^{\prime}$ 'alat) are also closely related to the ethical dimension of ethics in any action. For example, the major schools of Islamic law have unanimously agreed that void motives might lead to a contract eventually being nullified even if it satisfied the legal components of a valid contract. Moreover, ethical legality of a contract should also depend on its end user, which may be scrutinised through its outcomes and consequences emanating from its applications. Breaches of these ethical enterprises should be declared annulled although they meet some sort of legal pre-requisites.

There is in fact a long list of transactions and principles for applied ethics which might play important roles as guidance for scholars and experts in tackling various issues in contemporary societies. Scholars such as Ramadan ${ }^{68}$ and Moosa ${ }^{69}$ have discussed whether applied Islamic ethics may be exercised for environmental protection, medical sciences and services, politics, education, gender issues, and bioethics. In actual fact, whenever discussions are undertaken pertaining to Islamic guidelines in protecting the ethical dimension of an action, it is mainly centred on fiqh, and yet many are proposing that applied ethics is not actually a discussion about laws but about ethical values and intentions. We suggest that overemphasis upon Islam as a legal system is not really an effective solution for the development of the Ummah. Islamic development must be accomplished through its society rather than by imposing law which is normally part of the state apparatus. Defining Sharī 'ah merely as a system of laws is in fact calling for the state to guard and enforce it. However, the crucial need for Muslim societies nowadays is to be fully aware of the ethical dimensions of Shari 'ah and to apply them consciously, regardless of state intervention or non-involvement. ${ }^{70}$ This may possibly be accomplished, as proposed by Kamali, through persuasive measures and incentives, and by looking closely to the maqāsid guidelines. ${ }^{71}$ Moreover, this ethical approach in Shari ${ }^{\prime} a h$ is also crucial to overcome the literalist paradigm with its rigid dependency on the texts - regardless of the social, political, and economic context - in order to adequately face new challenges of our globalised world.

\section{The Challenges}

There are two main challenges that may be mentioned in our brief analysis for this proposal to be accepted and applied in Muslim societies at large. These challenges are:

- The existing dogmatic mindset among groups and individuals in Muslim societies. There are even certain Muslim scholars who uphold the belief that the structure of Islamic intellectual traditions were already well developed 
by the classical scholars, and have always been sceptic toward all new proposals for the renewal of the legal tradition. This type of frozen mindset needs to be faced wisely in order to bring ethical discourse within the sphere of Islamic jurisprudence.

- The challenge of bridging different fields of knowledge with variant methodologies, especially between the 'hard' and 'soft' sciences, in order to establish a holistic system of applied ethics which manages to provide better solutions for different aspects of human life. It is quite an effort to bridge the intellectual gaps among scholars of textual sciences and practitioners of contextual sciences, in order to integrate their perspectives and produce shared solutions for any particular problem. In order to do so, a common framework of integration between these different methodologies must be established to avoid piecemeal interactions, and fresh educational institutions are required.

\section{Conclusion and Recommendations}

The effort to present Islamic jurisprudence as an applied Islamic ethics is indeed a fresh approach in the field of Islamic law. This new attempt was proposed by some renowned Muslim scholars who made exhaustive efforts in order to manifest this ethical approach in all aspects of human life. Yet it also needs to be provided with viable methodologies benefiting from our reading of the textual and contextual inferences as the means to integrate different fields and disciplines for elaborating Islamic ethics, and for developing new classifications of higher objectives compatible with our needs and new realities. This effort, despite the hurdles it must overcome, should not be approached with scepticism or rejection, but be viewed as a creative attempt that may bring benefits for the development of the Ummah in our complex globalised world. Therefore, we propose certain measures to be taken into account by policy makers and government institutions in order to diffuse this idea of applied Islamic ethics within Muslim societies:

- The government should assist the society to establish an institution similar to the classical hisbah institution, whose role will be to promote and observe ethical practices in different life arenas such as banking and finance, medical services, food production, and environmental protection. This institution should be led by members of society themselves in their own locality and region, rather than by the government.

- It is important for both jurists and scientists to be well informed of the concept of applied Islamic ethics together with its principles and methodologies so as to provide better consultation to governments in searching for solutions to problems facing Muslim societies. 
- It is also necessary for governments to seek sound advice from informed scholars who are specialists in ethics, specifically in Islamic ethics and the ethical way to administer strategic national companies or revenues. It is worthy to note that Norway, one of the richest oil-exporting countries in the world with the highest living standard, hired Henrik Syse, a philosopher as an ethical advisor for the Norwegian Government's Petroleum Fund, in guiding the national company to spend its USD250 billion annual revenue. ${ }^{72}$

- Applied Islamic ethics should be introduced as a compulsory subject for Muslims, and even for non-Muslim students, within various fields of study in institutions of higher education.

- Intellectual discourse in the form of conferences, colloquia, and workshops may be organised on the national level, in specific localities and in certain institutions to elaborate and explore applied Islamic ethics relating to its scope and applicability in various practical areas.

\section{Notes}

* Ahmad Badri bin Abdullah is Research Fellow at IAIS Malaysia, with a focus on maqasid al-shari 'ah (the higher objective of Shari ah), usul al-fiqh, and contemporary Islamic jurisprudence discourse. He is pursuing his $\mathrm{PhD}$ in the study of maslahah.

1. Ebrahim Moosa and A.A. Mian, "Islam", in, Ruth Chadwick(ed.), Encyclopedia of Applied Ethics, (2012, San Diego: Academic Press), v.2, 769.

2. 'Ali Muhammad al-Sayyid al-Sharif al-Jurjani, al-Ta rifat, ed. Muhammad Siddiq al-Minsawi (Cairo: Maktabah Fadilah, n.d.), 141.

3. Yusuf al-Qaradawi, Madkhal li-Dirasat al-Shari'at al-Islamiyyah, (Cairo: Maktabah Wahbah, 2005), 8.

4. Jasser Auda, Maqāssid al-Sharīah As Philosophy of Islamic Law (Herndon \& UK: International Institute of Islamic Thought, 2010), 58.

5. Baber Johansen, "The Relationship between the Constitution, the Sharī'ah and the Fiqh: The Jurisprudence of Egypt's Supreme Constitutional Court", Zeitschrift für ausländisches öffentliches Recht und Völkerrecht, v. 64, no. 4 (2004), 882.

6. See Jasser Auda, Maqasid al-Sharī'ah, 59.

7. 'Abd al-Karim Zaidan, al-Madkhal Li Dirasah al-Shari'ah al-Islamiyyah, (1999, Beirut: Mu'assasah Al-Risalah), 172.

8. Cf., Jasser Auda, Maqasid al-Sharī'ah, 58.

9. Ibid.

10. Mohammad Hashim Kamali, An Introduction to Sharīa ah, (2006, Kuala Lumpur: Ilmiah Publisher), 17.

11. Mohammad Hashim Kamali, "Law and Ethics in Islam", in Kari Vogt, Lena Larsen \& Christian More (eds.), New Directions in Islamic Thought, (2009, London : I.B. Tauris), 35. 
12. See Majid Fakhry, Ethical Theories in Islam, (1994 E.J. Brill: Leiden, New York, Koln), 3.

13. Ibid.

14. Abdullah Hassan Zaroug, "Ethics from an Islamic Perspective: Basic Issues", The American Journal of Islamic Social Science, v. 16, no. 3, (1999), 59, 50.

15. A. Kevin Reinhart, "Islamic Law as Islamic Ethics", Journal of Religious Ethics, v.11 no.2: (1983), 186, 187, 205

16. Louis Pojman, Ethical Theories, (1995, London: Wadsworth), 4.

17. See John Rawls, A Theory of Justice, (1971, Cambridge, Massachusetts, London \& England: Harvard University Press), 11.

18. Ruth Chadwick, "What is 'Applied' in Applied Ethics?" Journal of Applied Ethics and Philosophy, (Sept, 2009), 2.

19. Cf. Louis Pojman, Ethical Theories, 5, 6.

20. Cf., Abdullah Hassan Zaroug, Ethics from an Islamic Perspective, 47-8.

21. A lecture by Jasser Auda $25^{\text {th }}$ April 2012, titled 'Islamic Ethics: Classical and Contemporary Perspectives', available online at: http://www.youtube.com/ watch?v=POWgUGJvUck./ (accessed on $1^{\text {st }}$ February 2014)

22. Umar F. Abdullah, "Theological Dimensions of Islamic Law", in: Tim Winter (ed.), The Cambridge Companion to Classical Islamic Theology, (2008, New York : Cambridge University Press), 246.

23. See Wael B. Hallaq, A History Of Islamic Legal Theories: An Introduction to Sunni Usul al-Fiqh, (2004, New York: Cambridge University Press), 136.

24. Muhammad Sa id Ramadan Al-Buti, Al-Madhahib al-Tawhidiyyah wa Falsafah al-Mu asirah, (2008, Damascus: Dar al-Fikr).

25. Cf., Umar F. Abdullah, “Theological Dimensions of Islamic Law”, 246.

26. 'Abd al-Jabbar, al-Mughni, (n.d., Cairo: Al-Muassasah al-Misriyyah) v. 14, 5.

27. Cf., Umar F. Abdullah, "Theological Dimensions of Islamic Law", 247.

28. Al-Bazdawi, Kitab Usul al-Din, (1969, Egypt: Isa al-Bab al-Halab), 131.

29. Sukrija Husejn Ramic, Language and the Interpretation of Islamic Law, (2003, Cambridge: The Islamic Texts Society), 3.41,102.

30. Cf., a lecture from Dr. Jasser Auda, refer note 17.

31. Ibn Qayyim al-Jauziyyah 'Ilam Al-Muwaqi in 'an Rabbil 'Alamin, $(1423 \mathrm{H}$, Riyadh: Dar Ibnu Jauzi), v.1, 14.

32. Abu Ishaq Ibrahim ibn Musa Al-Shatibi, Al-Muwafaqat fi Usul al-Shari'ah, 'Abd Allah Darraz (ed.), (2002, Beirut: Dar al-Ma'rifah), 1, 30.

33. Cf., Al-Shatibi, Al-Muwafaqat, v.4. 121, see also Ahmad Al-Raysuni, Imam alShatibi's Theory Of The Higher Objectives and Intents of Islamic Law, Nancy Roberts (trans), (2006, Herndon \& London: The International Institute of Islamic Thought), 138-9.

34. Muhammad Nasif al-Asari, al-Fikr al-Maqasidiy 'inda Imam Malik: Wa 'Alaqatuhu bi al-Munazarat al-Usuliyyah wa Fiqhiyyah fi Qarn al-Thani alHijri, (2008, Cairo: Dar al-Hadis), 338-9.

35. See Livnath Holtzman, "Ibnu Qayyim al-Jawziyyah", Essays in Arabic Literary Biography, J. E. Lowry and D. Stewart and (eds.), (2009, Wiesbaden: Harrassowitz Verlag), 201-22.

36. Cf., a lecture by Jasser Auda - 'Islamic Ethics: Classical and Contemporary Perspectives', refer note 19. 
37. Muhammad Khalid Mas'ud, Shatibi's Philosophy of Islamic Law,(1995, Kuala Lumpur : Islamic Book Trust), 105,105.

38. Cf., a lecture by Jasser Auda, refer note 19.

39. Cf., Al-Shatibi, Al-Muwafaqat, v. 2, 301, 305.

40. Cf., a lecture by Jasser Auda, refer note 19.

41. 'Ali bin Muhammad Al-Amidi (2003), Al-Ihkam fi Usul al-Ahkam, 'Abd alRazzaq al-Afifi (ed.), Riyadh: Dar Al-Sami i li al-Nasyr wa al-Tawzi, 139.

42. Wahbah Al-Zuhaili (1998) Usul al-Fiqh al-Islami, (2003, Damascus: Dar alFikr), v. 2.93.

43. Khaled Abou Fadl, Living in the light of God: Islamic Law and Ethical Obligation, available at http://wwwabc.net.au/religion/articles/2013/02/25/3697609.html, (accessed on 15th February 2014)

44. Habib Ahmed, "Defining Ethics in Islamic Finance: Looking beyond Legality" Eighth International Conference on Islamic Economics \& Finance: Sustainable Growth And Inclusive Economic Development from an Islamic Perspective 2011. Doha, Qatar, available at http://conference.qfis.edu.qa/app/media/290, (accessed on $16^{\text {th }}$ February 2014), 3 .

45. Cf., Mohammad Hashim Kamali, An Introduction to Sharī'ah, 44-5.

46. Cf., Baber Johansen, The Relationship Between the Constitution, the Shari'ah and the Fiqh, 892.

47. Waris Mazhari, Re-Imagining Islamic Ethics in the Context of Fiqh, available at http://twocircle.net/2007oct7/re_imagining_islamic_ethics_context_fiqh.html., (accessed on $20^{\text {th }}$ February 2014), 1 .

48. See Wael B. Hallaq, Was the Gate of Ijtihad Closed?, International Journal of Middle East Studies, Vol. 16, No. 1 (March 1984), 10.

49. Cf., Al-Shatibi, Al-Muwafaqat, v.2, 532.

50. Cf., Waris Mazhari, Re-Imagining Islamic Ethics, 4.

51. Sahih al-Bukhari, (Cairo: Dar al-Hadith), v. 41, hadith no. 582.

52. Ibid, 37 , hadith no. 448.

53. Cf., Habib Ahmed, Defining Ethics in Islamic Finance, 6.

54. Cf., A lecture from Dr. Jasser Auda, refer note 17.

55. Ibid.

56. Tariq Ramadan, Radical Reform: Islamic Ethics and Liberation, (2009, Oxford: Oxford University Press), 132.

57. Ibid, 136-7.

58. Cf., See Majid Fakhry, Ethical Theories in Islam, 1-8.

59. Abu Hamid Al-Ghazzali, Ihya' Ulum al-Din, Taha 'Abd al-Ra'uf Sa'ad (edit), (2003, Cairo: Maktabah al-Safa), v.2, 115.

60. M. Umaruddin, The Ethical Philosophy of al-Ghazzali, (2007, Delhi : Adam Publisher \& Distribution), 286.

61. Cf., Abu Hamid Al-Ghazzali, Ihya' 'Ulum al-Din, 85.

62. Cf., Al-Shatibi, Al-Muwafaqat, v. 1, 109.

63. George F. Hourani, Reason \& Tradition In Islamic Ethics, (2007, New York: Cambridge University Press), 45.

64. Robert Houghton, The Moral World of the Quran, available at http://www.onislam. net/english/reading-islam/research-studies/comparative-religion/449201-themoral-world-of-the-quran.html. 
65. Muhammad 'Abd Allah Draz, The Moral World of The Qur'an, Daniella Robinson \& Rabecca Masterton (trans), (2008, New York: I.B. Tauris), 8, 18, 56.

66. Cf., See Majid Fakhry, Ethical Theories in Islam, 108.

67. A lecture from Tariq Ramadan on 8th November 2012, titled 'The Need Of Ethics in Discussing Islamic Legislation' available at http://www.youtube.com/ watch?v=POWgUGJvUck, (accessed on 1 February 2014).

68. Cf., Tariq Ramadan, Radical Reform, 159, 181, 233.

69. Cf., Ebrahim Mossa \& A. A. Mian, "Islam”, 773-5.

70. See Henry Siegman, "The State and Individual in Sunni Islam" The Muslim World, v.54, no.1, (January 1964),14. See also N.J. Coulson, "The State and The Individual in Islamic Law" International and Comparative Law Quarterly, v.6, no.1, (January 1957), 49.

71. Mohammad Hashim Kamali, "Ethics and Finance: Perspectives of Sharī'ah and Its Higher Objectives" Islamic and Civilisational Renewal, v. 3, no. 4, (July 2012), 623.

72. Jim Sciutto, Philosopher Guides Norway's Oil Rich Spending Habits, available at http://abcnews.go.com/WNT/story?id=2009647\&, (accessed on 13 February 2014) 